\title{
İnşaat Proje Yönetiminde Sağlık ve Güvenlik Yönetim Sistemlerinin Kullanımı İçin Bir Yöntem
}

\author{
A Method for the Use of Health and Safety Management Systems in Construction Project \\ Management
}

\author{
Burak BİÇKES $^{1}$ (D), Gürkan Emre GÜRCANLI ${ }^{2}$ \\ ${ }^{I}$ İstanbul Teknik Üniversitesi, Fen Bilimleri Enstitüsü, Yapı İşletmesi, 34469, İstanbul, Türkiye \\ ${ }^{2}$ İstanbul Teknik Üniversitesi, İnşaat Mühendisliği Bölümü, 34469, İstanbul, Türkiye
}

$\ddot{O} \mathbf{z}$

İnşaat sektörü dünyada iş kazası ve meslek hastalığı sayısı en çok olan sektörlerin başında gelmektedir. Yaşanan iş kazaları gerek bireylere neden olduğu zarar açısından gerek ise iş yerine verdiği sosyal ve ekonomik zarar bakımından oldukça fazladır. Dolayısıyla işçi sağlığı ve iş güvenliği adına atılabilecek her adım iş kazalarını en aza indirgemek adına büyük bir öneme sahiptir. İş kazalarının meydana gelmesindeki en büyük nedenlerden bazıları, işçi sağlığı ve iş güvenliği farkındalığının yeteri düzeyde olmaması, yöneticilerin ve kontrolörlerin güvenlik konusundaki yanlış kararları, çalışma alanındaki karmaşıklık, araç ve gereçlerin güvensiz kullanım şekli ve emniyet tedbirlerinin yeterli seviyede olmaması olarak sıralanabilir. Ek olarak İSİG üyelerinin sahada gerçekleşen çalışmalardan ve inşaat iş programından haberlerinin olmaması, proje yönetim döngüsü ile iş güvenliği yönetim sisteminin farklı doğrularda gitmesine ve sahada iş kazalarının yaşanmasına neden olmaktadır. Buradan yola çıkarak her inşaat esnasında entegre edilmiş bir iş güvenliği yönetim sistemine ihtiyaç bulunmaktadır denilebilir. Bahsedilen sorunlara çözüm olabilmesi amacıyla bu makale kapsamında ISO 45001 standartlarına göre İSG iç tüzüğünden de yararlanılarak, inşaat iş programı ile işçi sağlığı ve iş güvenliği yönetim sistemi entegre edilmiştir. Öncelikle bu kapsamda konut projesi seçilerek, projenin iş programı çıkartılııștır. Ardından iş güvenliği yönetim sistemi kurulması için dört adet iş güvenliği uzmanı ile görüşülüp beyin firtınası metodu ile fikir alışverişi sağlandıktan sonra gerekli belgeler ve iş güvenliği aktiviteleri çıkartılmıştır. Son olarak ise oluşturulan iki sistem birleş̧irilmiştir. Yapılan çalışma sayesinde planlama, saha ve iş güvenliği ekiplerinin koordineli şekilde çalışması hedeflenmiştir.

Anahtar Kelimeler: Planlama, İş Güvenliği, İş Kazaları, Entegre Yönetim Sistemi, Proje Yönetimi

\begin{abstract}
Construction industry is one of the industries with the highest number of occupational accidents and diseases. Occupational accidents are quite high both in terms of the harm they cause to individuals and the social and economic damage they cause to the workplace. Therefore, every step that can be taken in the name of worker health and safety is of great importance in order to minimize work accidents. Some of the major causes of occupational accidents can be listed as insufficient occupational health and safety awareness, wrong decisions by managers and supervisors, complexity in the work area, unsafe use of tools and equipment, and insufficient safety measures. In addition, the lack of news about the OHS members from the works and construction work program in the field causes the project management cycle and the occupational safety management system to go in different directions and occupational accidents in the field. It can be said that there is a need for an integrated occupational safety management system during each construction. In order to solve these problems, ISO 45001 standard are used in this article and the occupational health and safety management system is integrated with the construction work program. Firstly, a residental project was selected and the work program of the project was prepared. Subsequently, four occupational safety experts were interviewed to establish an occupational safety management system, and after exchange of ideas with brainstorming method, necessary documents and occupational safety activities were issued. Finally, the two systems were combined. The aim of the study was to coordinate the planning, field and occupational safety teams.
\end{abstract}

Keywords: Planning, Occupational Safety, Work Accidents, Accident Statistics, Project Management, Integrated Management Systems

\section{GİRIŞ}

Tarihi insanlığın varoluşuna kadar dayanan, insanlık ve medeniyet için olmazsa olmaz bir faaliyet alanı olarak düşünülen inşaat sektöründe insanlığın gelişimine dayalı olarak evrimler yaşanmış ve günümüz ihtiyaçları ile bu evrimler, yapılara yansıyarak beraberinde riskleri de gündeme getirmiştir. Söz konusu risklerin varlı̆̆ı, yanında işçi sağlığı ve iş güvenliği kavramı üzerine çalışmaların başlamasına ve gelişmesine zemin hazırlamıştır. 
Bilinen ilk toplumlar olan avcı toplayıcı toplumlardan günümüze iş bölümünün belirginleşmesi, yapılan işlerin belirli bir prosedür içerisine yerleştirilmesi ve farklılaşması, hiç şüphesiz ki işi yapanın yani işçi olarak tanımlanan bireylerin sağlığını ve güvenliğini gerekli kılmıştır. Özellikle sanayi devriminde dikkat çeken sonrasında artarak yaşanan yoğun iş kazaları işçi sağlığ1 ve iş güvenliği kavramının tartışılarak tanımlanması gerekliliğini ortaya çıkarmıştır.

Yüzyıllar öncesinde başlayan bu gelişimlerden etkilenen sorunlar modern zamanlarda, risk analizlerinin, risk süreçlerinin, tedbirlerin, yasaların ve işçi sağlığı ve iş güvenliği çerçevesinde ele alınan tüm yapı taşlarının temelini oluşturmuştur. İşçi sağlı̆̆ ve iş güvenliği bilincinin oluşması için öncelikle riskin kazaya dönüşmesi gerektiği görüşü, yavaş yavaş günümüz iş sahalarında yerini tedbiri öngören sistemler üzerine çalışmayı, kazaların oluşumunu engellemeyi, risk meydana gelse dahi riskin işçi üzerindeki etkilerini en aza indirgemeyi hedefleyen sistemler oluşmasına birakmayı hedeflemelidir.

Tüm bunlara rağmen, işçi sağlığı ve iş güvenliğine özellikle Türkiye gibi gelişmekte olan ve gelişmemiş ülkelerde başta yeterince önem verilmemesinden dolayı birçok iş kazası meydana gelmektedir. Uluslararası Çalışma Örgütü'nün (ILO) 2016 Aralık tarihli Türkiye İşçi Sağlığı ve İş Güvenliği Profili'nde belirtildiği üzere, tüm dünyada her yıl 3 milyonun üzerinde kişi, iş kazaları ve meslek hastalıkları sonucunda hayatını kaybetmektedir [1]. Bunun yanında yine her yıl 300 milyon ölümcül olmayan iş kazası meydana gelmektedir. Sadece dünya inşaat sektöründe bir yıl içerisinde yaklaşık 60.000 iş kazası yaşanmaktadır. Bu hesaba göre işin ciddiyetini daha iyi idrak edebilmek için her 10 dakikada bir ölümcül iş kazası meydana geliyor denilebilir [1,2]. Fakat yine de, inşaat işlerinde iş kazalarının niteliği gereği, vücut bütünlüğünün bozulması ve ölüme varan sonuçların ortaya çıkması kaçınılmaz olmaktadır. TMMOB Mart 2018'de yayınladığı İş Güvenliği raporuna göre göre, 2012-2016 yıllarında genel olarak iş kazası sayılarında sürekli ve önemli artışlar görülmektedir [3].

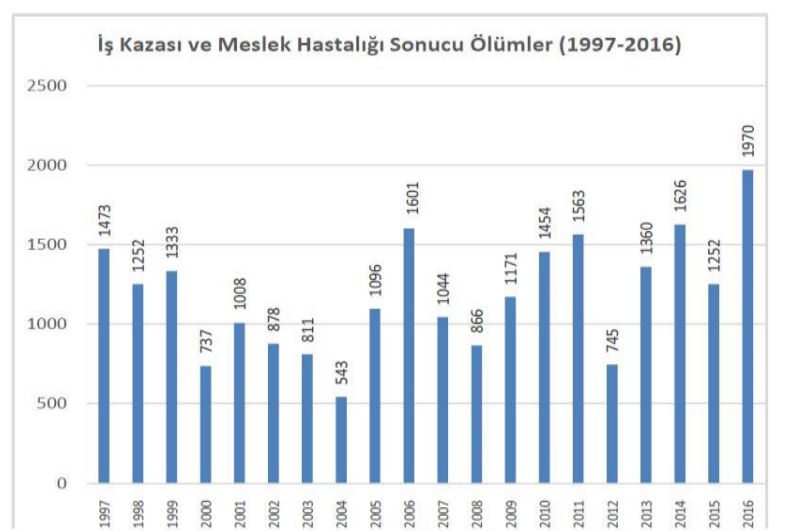

Şekil 1. Türkiye'de iş kazası ve meslek hastalığı sonucu ölümler [3]

Yaşanan iş kazaları arasında ki gerek ölümcül gerek ise ölümcül olmayan kazaların en fazla yaşandığı sektörün ise elbette büyük bir fark ile inşaat sektörü olduğu Şekil 2'de açıkça görülmektedir [3].

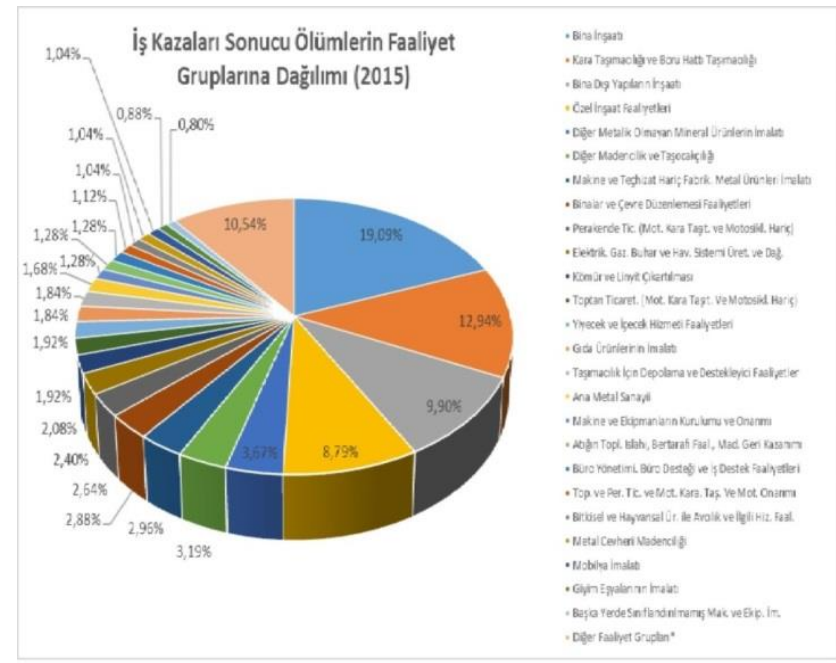

Şekil 2. Türkiye'de iş kazası ve meslek hastalığ1 sonucu ölümler [3]

Tüm bu istatistik bilgilere bakıldığında işçi sağlığı ve iş güvenliği konusunun ne kadar ciddi sonuçları olduğu görülmektedir. Mali kayıplar, iş gücü kayıpları, psikolojik bozukluklar bir kenara işin kalıcı hasar boyutu ve ölüm boyutu problemin önemini çok daha derinden vurgulamaktadır. Son yıllarda iş güvenliği ve işçi sağlığına verilen önemin artması, şantiyelerde ki daha sık1 kontroller, altyüklenicilerle yapılan iş güvenliğine dair yapılan ekstra sözleşmeler ve yürürlüğe giren iş güvenliğine ait kanunlara rağmen kazalar azalacağ 1 yerde tam aksine katlanarak artmaya devam etmiştir. Bu da açıkça ortada yönetim odaklı bir problemin olduğu gerçeğinin bir göstergesidir.

Özellikle gelişmekte olan ve az gelişmiş ülkelerde ki inşaat faaliyetlerinde görülen bir diğer sonuç ise iş kazalarının büyük firmalardan ziyade, orta ölçekli ve küçük ölçekli projelerde gerçekleştiğidir [4]. Küçük ve orta ölçekli inşaat firmalarında kaza oranlarının yüksek olmasının başlıca sebepleri, iş güvenliği ve işçi sağlığ1 bilincinin olmaması, yöneticilerin ve denetleyicilerin güvenlik konusunda ki kararları, tesislerde ki karmaşıklık, malzemelerin ve ekipmanların kalitesizliği, ekipmanları güvenli olmayan kullanım şekilleri ve emniyet yöntemlerinin yeteri düzeyde olmaması sayılabilir [5].

Türkiye İnşaat Sanayicileri İşveren Sendikası'nın 2018 Eylül tarihli İnşaat Sektörü Raporu'na bakıldığında 2017'de inşaat sektöründe çalışanların eğitim durumunun yalnızca $\% 26^{\prime} l 1 \mathrm{k}$ bir kismının lise ve yükseköğretim mezunu olduğu görülmektedir [6]. Bu orana bakılarak inşaat sektöründe en büyük paya kalifiye olmayan işçilerin sahip olduğu sonucu çıkmaktadır.

İşçi sağlığı ve iş güvenliği önlemlerinin alınmasında, çalışanların bilinçlendirilmesi ve eğitilmesi büyük 
önem taşımaktadır. Ülkemizde iş̧̧i sağlığı ve iş güvenliği konusunda dersler ilk olarak lise düzeyinde, mesleki ve teknik liselerde verilmeye başlanmaktadır. Bu eğitim daha sonra lisans ve lisansüstü daha kapsamlı olarak devam etmektedir. Uluslararası Çalışma Örgütü'nün 2016 tarihli Türkiye İşçi Sağlığı ve İş Güvenliği Profili’nde belirtildiği üzere, farklı alanlarda eğitim veren teknik liseler ve meslek liselerinde 9 . Sinıfta İSG hakkında genel bilgilendirme yapilırken, ileriki sınıflarda öğrencilere özelleştikleri alanlarda dersler verilmektedir [1]. Ancak inşaat sektörünün büyük kısmını kapsayan, lise veya üzeri eğitime sahip olmayan çalışanlar, yaptıkları işlerle ilgili bu nitelikte bir eğitim görmüş değildir. Ülkemizde faaliyet gösteren inşaat firmalarının çoğunluğunda, bu eksiği kapatabilecek şekilde işçi sağlı̆̆ ve iş güvenliği eğitimleri, ekstra maliyete ve zaman kaybına neden olduğu düşüncesiyle gerektiği ölçüde verilmemektedir. Meslek odalarının ve kamu kuruluşlarının verdiği eğitimler ise profesyoneller düzeyinde kalmaktadır. Bunun sonucu olarak iş̧̧ilerin büyük çoğunluğu, sahaya yeterli bilgi ve bilince sahip olmadan çıkmakta ve bu durum büyük tehlikelere yol açmaktadır.

İșçi sağlığı ve iş güvenliği önlemlerinin alınmasında diğer önemli ve gerekli husus, sahada yapılan işler esnasında ve öncesinde iş güvenliği ile ilgili fiziksel aktivitelerin yerine getirilmesidir. Ancak ne yazık ki ülkemizde yine birçok inşaat firmasında bu önlemler ya sadece görünürde alınmakta, ya da maliyet artı̧̧ına sebep olduğu veya gerek olmadığı gibi düşüncelerle göz ardı edilmektedir. $\mathrm{Bu}$ önlem yetersizliği, eğitimsizlikle birleştiği zaman iş kazaları kaçınılmaz olmaktadır.

Diğer bir açıdan bakmak gerekirse, bir projede üst düzey yöneticilerin tutumları genellikle proje müdürlerine, şantiye şeflerine ve denetleyicilere yansımaktadır. Yani üst düzey yöneticiler iş güvenliğine yeteri kadar önem vermiyorsa, zaten bu ortamda iş güvenliği performansını artırmak için neler yapılabileceğini düşünmek belki de zaman kaybı olarak görülebilir. Bu tarz bir atmosferde güvenlik ile ilgili sorumluluktaki mekanizmanın eksik olduğu aşikardır. Daha açık anlatmak gerekirse bir inşaat projesinde sorumluluk sadece iş güvenliği mühendisinde olmamalıdır. Projede ki tüm paydaşlar iş güvenliği ile konularda sorumlu olduklarını bilmeli ve ona göre davranmalılardır. Başta şantiye şefi olmak üzere saha sorumluları zaman, maliyet, kalite ve verimlilik gibi konular ile ilgilenmekten iş güvenliği ile ilgili konuları göz ardı edebilmektedirler [7].

İşçi sağlığı ve iş güvenliği konusunda eğitim ve fiziksel önlemlerin biliniyor olması, prosedürlerin düzenli bir şekilde uygulanması için yeterli değildir. Yapılan iş ile ilgili öncesinde sonrasinda ve sirasinda hangi durumlara bakılması gerektiğini çoğu durumda sadece tecrübeli bir iş güvenliği uzmanı bilebilmektedir. $\mathrm{Bu}$ açıdan birçok durumda böyle bir eksiklik olacağından dolayı yapılan işler gerekli kontroller yapılmadan veya tehlike içerisinde yapılmaya devam etmektedir. Bu açıdan her türlü işte her türlü kontrolü bilebilecek bir mekanizmaya ihtiyaç vardır. İş güvenliği departmanı ve planlama departmanı arasında bir ilişki olmalı yani işçi sağlığ 1 ve iş güvenliği, her inşaat projesi için özel olan iş programından bağımsı olarak düşünülmemelidir.

Tüm bu yukarıda sayılan problemler doğrultusunda işçi sağlığ 1 ve iş güvenliği konularına farklı bir boyuttan bakmak gerektiği açıkça ortadadır. $\mathrm{Bu}$ açıdan değerlendirmek gerekirse, etkin bir planlamanın projelerin başarısında önemli bir rol oynayabileceği yaygın olarak kabul edilmektedir. Çünkü genellikle, projeyi planlama eylemi kendi başına başarıyı garanti etmeyecek olsa da, "planlamanın olmaması muhtemel başarısızlığı garanti edecektir' ilkesi kabul edilir [8].

Belirtilenler doğrultusunda bu çalı̧̧ma kapsamında, inşaat projelerinde süresel planlama ile İşçi Sağlığı ve İş Güvenliği Yönetim Sistemi entegre edilerek, bütünleşik bir güvenlik planlaması oluşturulması amaçlanmıştır. Bu çalışma aynı zamanda yüksek lisans tezi kapsamında gerçekleştirilmiş bir üründür ve oradan esinlenilmiştir. $\mathrm{Bu}$ çerçevede, inşaat projesi kapsamındaki aktivitelerin planlanması sırasında, işçi sağlığı ve iş güvenliği aktivitelerinin de aynı anda takip edilebilmesiyle, meydana gelebilecek iş kazalarının önüne geçilmesi hedeflenmektedir.

Bu yapılan çalışma ile şantiyede çalışmalar başlamadan önce oluşturulan bütçe ve süresel planlama gibi önceden hazırlanması gereken evraklara ek olarak iş güvenliği ile ilgili önlemlerde birer aktivite olarak çıkarılmıştır. Çıkarılan iş güvenliği aktivitelerinin iş planıyla birleşmesiyle de planlama departmanı vasitasıyla saha ekiplerinin ve iş güvenliği birimlerinin birbirleriyle daha koordineli çalışmaları ve daha sorunsuz bir iletişimleri olması sağlanmaya çalışılmıştır. Bu şekilde işin daha az tehlikeli olabilmesi için gerekli koşullar saha ekipleri tarafindan da bilinip bilinçaltında takip edilebilirliği oluşacaktır. Böylece önlemler iş gerçekleşmeden önce daha rahat alınabilecek ve iş güvenliği ile ilgili belgeler sadece iş güvenliği birimleri tarafindan değil saha ekipleri tarafından da farkındalığı artacağı düşünülmüştür.

Aynı zamanda Şekil 3’te Risk Kontrol Hiyerarşisi'nde de görüldüğü üzere, bu yapılan çalışma Risk Kontrol Hiyerarşisi'nin daha en başında sağlık ve güvenlik önlemlerinin alınabileceği varsayımından hareket etmektedir [9]. Zira tasarım ve planlama yoluyla daha proje başlamadan riskler saptanabilir ve azaltmak için gerekli tasarım/planlama değişiklikleri yapılabilir. $\mathrm{Bu}$ çalışmada önerilen yöntem bahsedilen amacın gerçekleştirilmesi için bir araç sunmaktadır.

Kısaca özetlemek gerekirse, iş güvenliği ve işçi sağlığ yönetim sistemi ile iş programı entegre edilerek iş güvenliği ile tedbirlerin sadece saha esnasında alınmasıyla kalınmayacak, yapımdan önceki tasarım ve 
planlama aşamalarında da iş güvenliği tedbirleri düşünülerek yaralanmaların, mesleki hastalıkların ve en kritik olanı ölümlerin önüne geçilmeye çalışılmıştır.

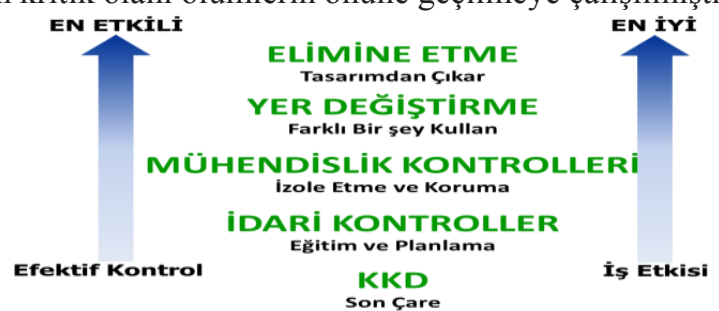

Şekil 3. Risk Kontrol Hiyerarşisi [9]

\section{MATERYAL ve YÖNTEM}

Makale çalışmasında öncelikle değinmek gerekirse OHSAS 18001 ve ISO 45001 standartlarına göre işçi sağlığı ve iş güvenliği ile form, tutanak, talimatlar, yönetmelikler vb. gibi tüm belgelerin derlenme işlemleri yapılmıştır. Fakat OHSAS 18001 değişerek yerine ISO 45001 geldiğinden dolayı çalışmanın ana yapısı ISO 45001 üzerine dayandırılmıştır. Projenin işçi sağlığ1 ve iş güvenliği yönetimi kapsamında takip edilen ana kaynak, ISO 45001 - İşçi Sağlığı ve İş Güvenliği Standardı ve İSG İç Yönetmeliğidir.

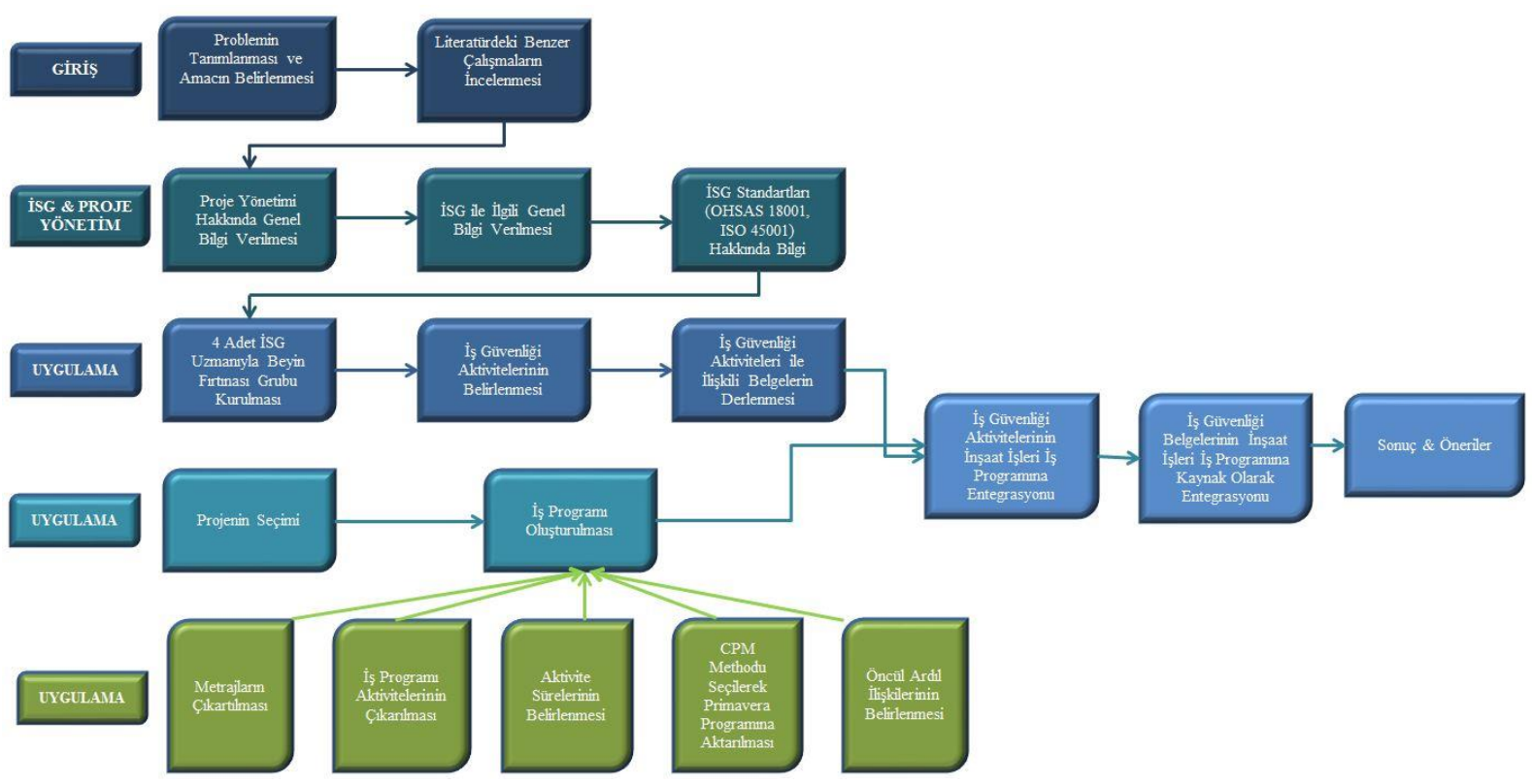

Şekil 4. Çalışmanın Akış Şeması

Primavera P6'ya aktarılmış projeye ait iş kalemlerinde uygulanacak olan işçi sağlığı ve iş güvenliği talimat, form, prosedür ve tutanakları, İSG İç Yönetmeliği'ne göre belirlenmiştir.

Uygulama için genel olarak inşaat sıklığı nedeniyle konut projesi seçilmiştir. Konut projesine esas olan yap1

ise İstanbul ili Küçükçekmece hudutlarında bulunan oturum alanı yaklaşık $400 \mathrm{~m}^{2}$ olan ve 1 bodrum kat, 1 zemin kat ve 7 normal kattan betonarme bir yapıdır. Projede tünel kalıp ve prekast cephe kullanılmıştır.

Uygulamaya esas olan binanın projeleri, bu projenin planlama işini yapmış olan uzman bir planlama mühendisinden alınmış ve iş programında kullanılmak üzere metrajları çıkartılmıştır. Ardından iş programına ait inşaat işleri aktiviteleri oluşturulmuştur. Sonrasında her bir aktivite için verimlilikler düşünülerek aktivite süreleri belirlenmiştir. Süresel planlama teknikleri arasından Kritik Yol Metodu seçilmiştir ve bunun için Primavera P6 programı kullanılmıştır. Son olarak inşaat işleri aktiviteleri arasında öncül ve ardıl ilişkiler girilmiştir. Aktivitelerin bağlanması sırasında, ilişkiler aktivite türüne göre start to start, start to finish, finish to start ve finish to finish ve aynı zamanda gerekli bolluklar ve gecikmelerde verilerek kurulmuştur. Sonuç olarak inşaat işleri iş programı oluşturulmuştur.

Burada iş kalemleri aktivite koduna göre ayrılması yapılmıştır. Aktivite kodunda ayrılmasının sebebi her bir aktiviteyi kendi kod grubuna göre sınıflandırmaktır. Aynı zamanda iş kırılım yapısına göre de aktiviteler gruplandırılmıştır. Aktivite kod olarak aktiviteler 4 ana başlığa bölünmüştür. Bunlar;

- İmalat Tipine,

- İnşaat Türüne,

- İş Güvenliği ile İlgili Belge Türüne,

- Kat Bazına göre oluşturulmuştur.

Diğer bir bölüm olan iş güvenliği ve işçi sağlığı ile ilgili tüm aşamalar 2 adet A sınıfı, 2 adet B sınıfı iş güvenliği uzmanı ile görüşülerek yürütülmüştür. Bunun için öncelikle 5 kişiden oluşan beyin firtınası grubu kurulmuştur. 4 kişilik iş güvenliği uzmanı ile iş 
programında ki her bir kalem için gerekli olan dokümanlar belirlenmiştir. Aktivitelerle ilişki kurulması gereken farklı türlerde belgeler bulunmaktadır. $\mathrm{Bu}$ türlerden bazıları ve en yaygın olarak kullanılanları aşağıdaki gibidir;

- Talimat: Aktivite boyunca uyulması gereken kuralları içeren belgelerdir.

- Form: Aktivite öncesinde hazırlanmas1 gereken ve türüne göre aktivite başında, sirasinda veya sonunda doldurulması gereken belgelerdir.

- Prosedür: Aktivite boyunca uyulması gereken kuralları içeren belgelerdir.

- Tutanak: Aktivite öncesinde veya sonrasinda hazırlanması gereken ve türüne göre aktivite başında, sırasında veya sonunda doldurulması gereken belgelerdir [9].

İnşaat işleri aktivitelerine karşılık gelecek iş güvenliği aktiviteleri belirlendikten sonra ISO 45001 standartlardında ki dosyalardan yararlanarak belgeler bulunmuştur. $\mathrm{Bu}$ belgeler işçi sağlı̆̆ ve iş güvenliği aktivitelerine programda kaynak olarak atanmıştır.

Son olarak ise; Süresel planlama Primavera P6'da oluşturulup, İSG yönetimi için gerekli belgeler derlendikten sonra, bu iki sistemin entegrasyonu sağlanarak güvenlik planlaması yapılmıştır. Bu süreçte sürecin süresel anlamda etkilenmemesi amaciyla bazı kabuller yapılmıştır;

- Aktiviteler başlamadan önce imzalanması gereken formlar, aktivite başlamadan 1 gün önce tamamlanacak şekilde aktivitelere bağlanmıştır.

- Her aktivite için, o aktivite özelinde uyulması gereken prosedür ve talimatlar, ilgili aktivite başlamadan 1 gün önce başlayıp, aktivite süresince devam edip, aktivite ile tamamlanacak şekilde oluşturulmuştur.

- Proje süresince tüm aktivitelerde uyulması gereken genel talimat, form, kontrol listesi ve prosedürler belirlenerek (Şahsi Koruyucu Malzemeler Kullanımı İş Güvenliği Talimatı, İşçi Sağlığı ve İş Güvenliği Talimatı, Tehlike ve Risk Değerlendirme Prosedürü gibi) proje başlangıcında başlayıp, proje bitiminde tamamlanacak şekilde atanmıştır.

- Verilmesi gereken iş güvenliği eğitimleri proje başlangıcında başlayıp, proje sonunda bitecek şekilde oluşturulmuştur.

Bu kabullere dayanarak, iş programı güncellenmiştir.

İnşaat endüstrisi diğer endüstrilerle bağlantılı olarak kaynaklanma ve planlı olma eğilimindedir ve bu, iş güvenliği ve işçi sağlığını etkileyebilecek inşaat kültürü özelliği olan her türlü üretim riskine bir kriz yönetimi yaklaşımını teşvik eder. Buna karşın sadece yüksek planlı işler neredeyse her zaman sorunsuz bir şekilde çalışabilir. Bu tür çalışmalar son derece odaklanılmış bir şekilde yönetilir ve çok detaylı bir şekilde planlanır. Rutin işler bile daha kesin kısa vadeli planlamalardan faydalanabilir. Aynı şekilde iş güvenliği ve işçi sağlığı konularının da aynı yaklaşımdan faydalanmaması ve en azından bu derecede geliştirilmemesi için hiçbir neden yoktur [10].

Günümüzün düşüncesi, eski üçgensel zaman, maliyet, kalite konularından birindeki bir iyileşmenin diğerlerinde bozulmaya yol açtığı değiş tokuş modeline ciddi bir şekilde meydan okumaktadır. $\mathrm{Bu}$ da artık 'kalite ücretsizdir' denen toplam kalite yönetimi felsefesinin genişlemesine sebep olmaktadır [11]. Aynı zamanda güvenlik alanındaki verimliliklerin zaman ve maliyet gibi diğer alanlarda da fayda sağlayabileceğine hedefini taşımaktadır. Etkili bir inşaat planlamasının ve kontrolünün sağlı ve güvenlik risklerinin önlenmesinde önemi göz ardı edilemez [12].

Proje yönetimi konulu yayınlarda 1990'lı yılların sonlarından itibaren işçi sağlığı ve iş güvenliği konuları öne çıkmaya başlamıştır. İşçi sağlığı ve iş güvenliği yönetiminin proje yönetimine entegrasyonu konulu bu çalışmanın ortaya çıkmasına temel oluşturan literatürdeki bazı çalışmalar ile ilgili özet bilgiler aşağıda verilmiştir:

İlk olarak, Tarrants 1980 yılında yaptı̆̆ı bir çalışmada iş güvenliğinin planlanmasının ve bu sürecin yönetilmesinin tasarım aşamasında inşaat yönetimi bünyesine girmesi gerektiğine değinmiştir [13]. Kartam ve Levitt 1990 yılında yaptıkları çalışmada işverenlerin altyüklenicilerini güvenlik açısından ön kalifiye etmeleri gerektiğine inanarak, işveren penceresinden altyüklenicilerin iş güvenliği ve sağlığı konusunda ne derece önem verdiklerini analiz edici bilgisayar destekli bir program olan SAFEQUAL' i üretmişlerdir. SAFEQUAL altyüklenici firmaya 4 sayfalık bir anket gönderen bir uygulamadır. Aynı zamanda SAFEQUAL ankete alt yüklenicinin verdiği yanıtları yorumlamada veya bir müteahhidin beklenen güvenlik performansının değerlendirmesini haklı çıkarma yetkisi veren kapsamlı bir kontrol listesine benzeyen basit bir sistemdir. $\mathrm{Bu}$ sayede işveren henüz teklif aşamasındayken bile altyüklenicinin iş güvenliğine karşı bakış açısını değerlendirme firsatı yakalamış olmaktadir [14].

Kartam tarafından 1997 yılında yapılan çalışmanın bu makale kapsamı ile büyük benzerlik taşıdı̆̆ görülmüştür. Kartam, makalesinde inşaat kazalarının birçok insan trajedisine neden olduğundan, inşaat işçilerinin demotivasyon oluşundan, inşaat süreçlerine zarar verdiğinden, ilerlemeyi geciktirdiğinden ve inşaat endüstrisinin maliyetini, verimliliğini ve itibarını olumsuz yönde etkilediğinden bahsetmiştir. Öte yandan, mal sahibinin inşaat sırasında işin güvenli gittiğini izlemek ve kontrol etmek isteyeceğini ve iş güvenliği planlarını bir yüklenici seçiminde kriter olarak değerlendirmek için etkili bir araca ihtiyaç 
duyacağın savunmuştur. Ek olarak zamanlamanın, maliyetin, üretimin ve kalite kontrolün her sorumluluk seviyesindeki iyi düşünülmüş bilgisayarlı planlar ve kontrollerle yönetilmesinden bahsetmiş, buna karşılık ise iş güvenliği ve sağlık uzmanlarının gerçekten ihtiyaç duyulan bir entegre güvenlik yönetim sisteminin olmadığına dikkat çektiğinden bahsetmiştir. Sonuç olarak, tüm bunlar düşünüldüğünde proje yönetim tabanlı bir tedbir bulunması gerektiğini dile getirmiştir. Bu bağlamda, planlama için CPM (Kritik Yol Metodu) esas alınmış ve bu yönteme paralel bir yazılım sistemi geliştirilmiştir. Bu sistem kapsamında, projedeki tüm faaliyetler ile işçi sağlığ ve iş güvenliği yönetmelikleri, Kartam tarafından geliştirilen IKISSAFETY yazılımı ile entegre edilmiştir. Kartam, entegrasyon sisteminde CPM'den farklı bir yazılım kullanmasının sebebinin CPM'in mevcut haliyle bir inşaat projesi için yeterince karmaşık olduğuna dayandırmıştır. Bunun içinde CPM üzerine ayrı bir yazılım tarafından eklenen bağlantılar ile sürecin izlenebilirliğini kolaylaşacağını savunmuştur [15].

Saurin ve arkadaşları 2001 yılında yaptıkları çalışmada iş güvenliği yönetim sisteminin, belirli bir düzende planlama sistemine entegre edilebileceği SPC adında bir modele değinmiştir. Bu makale kapsamına konu olan çalışma ile oldukça benzerlik taşıdığı en önemli yanı ise bahsedilen modelin küçük çaplı bir konut projesi üzerinde denenmesidir. 2001 yılında yapılan bu çalışma sonucunda, Last Planner metodu gibi üretim planlama ve kontrolünde başarıyla kullanılan kavram ve yöntemlerin emniyet planlamasina da uyarlanabileceğini göstermiştir. Buna ek olarak planlama toplantıları içerisinde iş güvenliği planlamasının ve kontrolünün de bulunması gerektiği düşünülmüştür. Aynı zamanda bunun çok fazla zaman kaybına sebebiyet vermeyeceğini de gösterilmiştir [16].

Yapılan literatür taramasına baktığımızda 1980 yılından günümüze kadar yapılan çalışmalar sundukları öneriler açısından benzerlik taşımaktadır. Tüm bu çalışmalardan iş güvenliğinin sadece yapım aşamasında ki tedbirlerle sınırlı kalınmaması gerektiğine ve tasarım ve planlama süreçlerine entegre edilmesi gerektiği sonucuna ulaşmak zor değildir. Ancak yapılan tüm bu çalışmalara rağmen ne yazık ki proje süresel yönetimi ve işçi sağlığı ve iş güvenliği yönetiminin entegrasyonu konusunda somut adımlar atılmadığ1 görülürken, uygulanmakta olan bir yönteme de rastlanmamıştır.

\section{BULGULAR ve TARTIŞMA}

1997 yılında ISO, işçi sağlığı ve iş güvenliği yönetim sistemi geliştirmemeye karar verdi ve bu sebeple birçok ülke kendi iş güvenliği yönetim sistemlerini geliştirme kararı almıştır. BSI tarafından 1996 yılında BS 8800 adı altında bir standart üretildi. Bu standart HSE ve ISO 14001 'den gelen yönetim sistemleri modellerine dayanarak bir rehberlik belgesi olarak yazıldı. BS 8800 genel olarak, mevcut bir işçi sağlığ 1 ve iş güvenliği yönetim sistemi ile eksiklikleri nasil değerlendirebilirim, yeterli bir sistem ne içermelidir ve mevcut sistemden yeterli bir sisteme nasıl geçilir gibi konular hakkında tavsiye vermektedir. BS 8800 yayınlandıktan sonra ilk 1 yıl içerisinde 7000'den fazla satışı gerçekleşmiştir. Ardından 1999 yılında OHSAS 18001, BSI tarafından yönetilen çeşitli kuruluşlar tarafından üretilmiştir. Bu kuruluşlar hem İngiltere'den hem de uluslararası camiadan gelen kuruluşlardır. OHSAS 18001 'de kullanılan yönetim sistemi modeli ISO 14001 modelidir. Bir standart olarak, OHSAS 18001, organizasyonun her bir fonksiyon ve organizasyon düzeyinde, belgelendirilmiş sağlık ve güvenlik hedeflerini belirlemesi ve sürdürmesi gibi ifadeleri kullanarak bir dizi yönetim sistemi gereksinimi listelemektedir [17].

OHSAS 18001, 2007 yılında ise güncellenmiştir. Fakat her ne kadar OHSAS 18001 yaygın olarak kullanılsa da bir ISO belgesi değildir. Bu yüzden son y1llarda ISO 45001 adı altında bir standart geliştirilmektedir. ISO 45001 standard 1 , OHSAS 18001 standard 1 yerine hazırlanmakta olan yeni işçi sağlığı ve iş güvenliği yönetim standardıdır. ISO 45001'in kapsamı Şekil 5'te de gösterildiği üzere liderlik ve işçi katılımına dayalı planlama, destek ve çalışma, performans değerlendirmeleriyle birlikte de sürekli iyileştirmeyi hedefleyen bir yapıya dayanmaktadır.

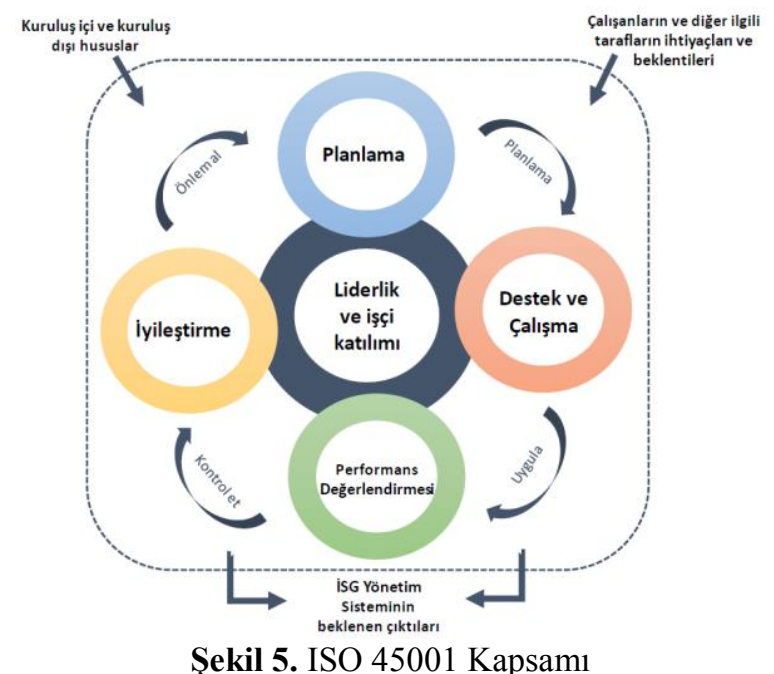

Makale kapsamında İşçi sağlığı ve iş güvenliği yönetim sistemi oluşturabilmek için beyin firtınası kullanılmıştır. En çok bilinen ve halk arasında geçen uzman görüş yöntemlerinden biri olan beyin firtınası uzman görüş yöntemi farklı türlerde belirtilebilmektedir. Çoğunlukla araştırma tekniği olarak kabul görülürken, bazıları kişi veya kurumlarca yöntem, problem çözme metodu olarak da kullanılmaktadır. Yöntem; en temel anlamıyla birden çok katılımıının bir araya gelerek bir konuyla ilgili düşüncelerini tartışmaksızın açıklayarak, birbirleriyle fikir alışverişinde bulundukları, kişinin yaratıcı düşünme gücünü geliştiren bir öğretim tekniğidir. Bu 
teknik, eleştiri ve yargılama olmadan, bir konu üzerinde her türlü fikrin yüksek sesle dile getirilmesi temeline dayanan, yaratıcı düşünceleri ortaya çıkarmak amacıyla kullanılan tekniklerden biri olarak ifade edilebilir.

Yapılan literatür taramasında bu yöntem ilk kez Osborn tarafından 1957 'de pazarlama sektörü ile kullanılmaya başlanmış olup, sonrasında 1971'de Davies tarafindan psikolojide kullanılmaya devam edilmiştir [18,19]. Orlich'e göre, beyin firtınasını bir yöntem olarak değil etkinlik şeklinde görmekte ve düşünce-görüş kazandırma ve yeni fikirlerin ortaya atılmasında öğretimsel amaçları olduğunu savunmaktadırlar [20]. Demirel ise, beyin firtınasını hayal yoluyla düşünce ve fikir üretmek için kullanılan yaratıcı bir teknik olarak tanımlamaktadır [21].

Katılımcıların eleştirilme endişesi olmadan fikirlerini rahatlıkla ifade ettikleri bir grup tartışma tekniğidir ve birçok katılımcının bir araya tek bir oturumda gelmesi kısa sürede çok sayıda farklı fikir üretilmesini sağlar. Bir moderatör yönetiminde katılımcılara yapılan sunuşun ardından katılımcılar fikirlerini beyan eder ve tüm fikirleri not alınır. Süreç içerisinde uzmanlar fikirler arasında bağlantılar tespit ederse bu fikirler birleştirilebilir. Her sorun veya konu üzerinde en son tartışma ve analiz sağlanarak ortak bir görüş oluşturulmaya çalışılır.

Bu makale kapsamında, İSİG Bilgi Belge Yönetim Sistemi entegrasyonuna yönelik yapılan çalışmada ise ortalama 10 - 15 yıl inşaat sektörü tecrübesine sahip 2 adet A sınıfı, 2 adet B sınıfı iş güvenliği belgeli ve bir de benden oluşan 5 kişilik bir beyin firtınası grubu kurulmuştur. 5 kişilik bu beyin fırtınası grubu sayesinde İSIG bilgi belge yönetim sisteminin bileşenleri oluşturulmuş ve bu bileşenlerin belirlenen iş kalemlerine entegrasyonu sağlanmıştır.

Bu kapsamda içerik olarak;

1. İSIGG Yönetim Sistemine İlişkin Belge Türlerinin neler olacağ

2. İSIGG Yönetim Sistemine İlişkin İş Kalemleri belirlenmiş,

3. İSIG Yönetim Sistemine İlişkin Belgelerin (Kaynakların) Tedariği yapılmış,

4. İSİG Yönetim Sistemi ile İnşaat İşleri İş 5. Programının entegrasyonu yapılmıştır.

Beyin firtınası grubu ile işçi sağlığı ve iş güvenliği yönetim sisteminin kurulması 2 aşamada gerçekleşmiştir. Beyin firtınası grubu ile yapılan çalışmanın ilk oturumunda bir konut projesinin inşaatı işinde işçi sağlığı ve iş güvenliği yönetim sistemi dokümantasyonu için en çok kullanılan belgeler belirlenmiştir. Bunlar, talimat, prosedür, form, tutanak, tehlike ve risk değerlendirme, kaza ve olay tespit, eğitim, acil durum planları ve kontrollerdir. Aynı zamanda İSIGG yönetim sisteminde olması gereken iş güvenliği aktiviteleri listesi çıkartılmıştır. Aktivite listelerinden kasıt, iş güvenliği belgelerinin çeşitlerinin isim olarak belirlenmesidir. Bilinildiğgi üzere iş güvenliği konusunda doldurulması gereken tek bir form veya uyulması gereken tek bir prosedür veya talimat yoktur. Örnek olarak göstermek gerekirse;

- Şantiye Alanına Giriş İzni Formunun Doldurulmas1,

- Yüksekte Çalışma Prosedürüne Uyulması,

- Acil Durum Müdahale Ekipleri Listesinin Belirlenmesi, gibi iş kalemleri sayılabilir.

Son olarak ise kullanılacak bu belgelerin tedarik edilmesi yapılmıştır. Sağlık, Emniyet ve Çevre (SEÇ) Politikasının belirlemiş olduğu dokümanlardan, beyin firtınası grubunda $\mathrm{ki}$ iş güvenliği uzmanlarının kullandıkları belgelerden ve tüm bu süreçler için ISO 45001 standardından da yararlanılmıştır. Bu sayede her çeşit belge türü için iş güvenliği aktivitelerin içerisinde örnekleri de bulunabilmektedir.

İkinci oturumda ise belirlenen İSİG Bilgi Belge Yönetim Sistemine ilişkin belgelerin yapım sürecinde hangi imalat kalemleri ile ilişkili olduğu, hangi tip ilişkide olduğu, hangi imalatlardan önce ve sonra hangi belgelerin hazırlanması gerektiği, alınması gereken izinler, alınması gereken güvenlik önlemleri gibi İSİG sistemi ile inşaat uygulama iş kalemlerinin birbirlerine ilişkilendirilmesine ilişkin asıl bütünleşik sistem oluşturulmuştur.

Aktarılan inşaat işleri iş programı bilgileri ile işçi sağlığ ve iş güvenliği yönetim sistemi ile ilgili bilgilerin birleştirilmesi ile ilgili olarak en başta yapılan hamle planlama esnasinda aktivite kod yapisı oluşturmaktır. Aktivite kod yapısını oluşturmakta ki en önemli amaç karmaşıklıktan kaçınılarak aktiviteleri türlerine göre ayrıştırabilmek ve yeri, zamanı geldiğinde veya ihtiyaç duyulduğu anda kendi grupları halinde kullanıcıya sunabilmektir. Aktivite kod yapısı aşağıda gösterildiği üzere 4 ana başlıkta oluşturulmuştur:

- IMALAT Tİİ

- INS

- ISG

- KATLAR

İmalat tipine göre kodları ayırmanın mantığı aktivitenin ilk bakışta kolayca iş güvenliği mi yoksa inşaat işlerine mi ait bir aktivite olduğunu anlayabilmektir. Bunun için Aktivite ID sütunu adı altında zaten aktivite isimlerinin sonuna kolayca anlaşılabilmesi için "'-ISG' terimi eklenmiştir. Fakat aktivite kod yapısının da içerisinde bunun barınması için İmalat Tipi adı altında bir başlık açilmıştır.

INSS kodu aktivitenin inşaat işlerine ait bir aktivite olduğunu belirtmektedir. Benzer şekilde ISG kodu ise aktivitenin işçi sağlığ ve iş güvenliği yönetim sistemine ait bir aktivite olduğunu ifade etmektedir. INNS ana başlığı oluşturmakta ki amaç, inşaat işlerine ait bir aktivitenin aslında iş kırılım yapısına (WBS) göre 
gruplandırmasının yapılabilmesinin sağlanmasıdır. Mobilizasyon aşamasına ait aktiviteler ve proje başlangıcı ve bitişlerinin yapıldığı kilometre taşları ", MOB" kodunda girilmiştir. Kazı, dolgu ve bunların nakliyesi gibi inşaat işleri aktiviteleri ise "'GEO', kodunda düşünülmüştür. Temel, bodrum katı, normal katlar ve asansör kulesinde yapılan betonarme işleri ve prekast elemanların işlerine ait iş kalemleri ise "KABA', aktivite kodunda toplanmıştır. Belki de en çok iş kaleminin içerdiği "INCE'" aktivite kodu ise bina ile ilgili tüm mimari işleri içeriğinde barındırmaktadır. Planşe ve borulama, desant kablo işleri, asansör imalatı, ana besleme hatları, pano ve sigortalar, anahtar ve priz montajları, aydınlatma armatürleri ve test ve devreye alma gibi tüm elektrik işleri ise "'ELK', aktivite kodundan girilmiştir.Son olarak, pis ve temiz su tesisatları, kalorifer tesisat1, doğalgaz boruları, vitrifiye armatür ve duşakabin montajları gibi tüm mekanik imalatlar ise "MEK', kodunda olması düşünülmüştür.

İşçi sağlığı ve iş güvenliği ile ilgili formlar ' $F R M$ ', aktivite kodu ile ifade edilmektedir. Uygunsuzluk Tespit Tutanağı, İşyerinde Uyulacak İşçi Sağlığı ve İş Güvenliği Kurallar Tutanağı Gibi Tutanaklar ise ' 'TUT' kod yapısında düşünülmüştür. İşçi sağlığı ve iş güvenliği yönetim sisteminde ki dokümanlarda en çok kullanılanlardan biri olan prosedürler ise 'PRO', aktivite kod yapısı altında toplanmıştır. En başta işin başlangıcında ve yeni iş birimlerinin devreye girmesiyle belirli periyotlarla güncellenmesi gereken risk değerlendirme çalışmaları ise "'RDE", ile gösterilmiştir. İş yerinde en çok sakınılan eylem olan kazalar ise, bu anda nelerin gerektiğini belirlemek için oluşturulan Kaza Olay Tespit dokümanları ' 'KOT', adı altında oluşturulmuştur. İşçilerin bilinçlenmesi bir proje de kazaları engellemenin en önemli faktörüdür. $\mathrm{Bu}$ açıdan verilen eğitimler ise 'EĞT', ile belirtilmiştir. İşçi sağlığı ve iş güvenliği ile ilgili kontroller ise ' $K N T$ ' ile ifade edilmiştir. Sel, deprem, yangın gibi acil durumlarda ise ayarlanması gereken acil durum halleri dokümanları "'ACL" kodu ile ifade edilmiştir. ISG aktivitelerine ait aktivite kod yapısı Şekil 6 üzerinde gösterilmiştir.

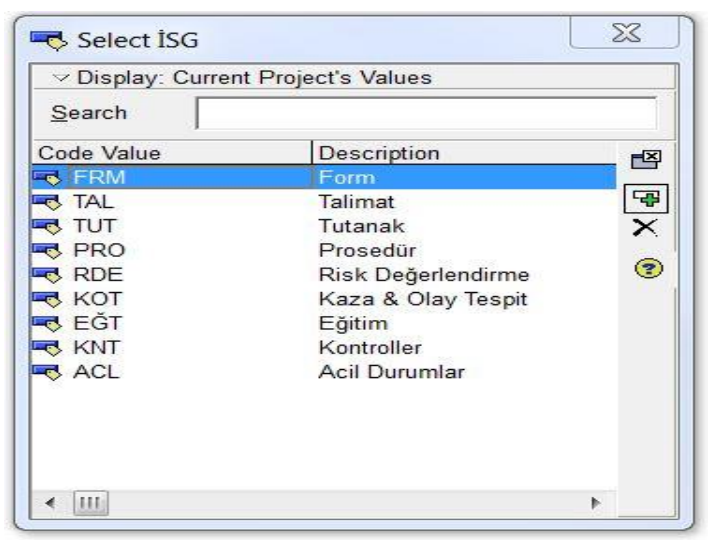

Şekil 6. İSG aktivite kod yapısı.
K7, K6, K5, K4, K3, K2, K1, KZ, KB1 gibi başlıklar katlarda yapılan aktivitelere atanmıştır. Terasta yapılan işlemler ise "KÇATI" kod yapısı altında düşünülmüştür. Bazı imalatlar ise sadece bir kattan bağımsız genel olarak tüm proje için geçerlidir. Bunları kat bazında ayarlayabilmek adına ise "TÜM" adı altında bir kod yapısı oluşturulmuştur.

Belirlenen imalatlardan önce bitirilmesi veya doldurulması gereken formlar aktiviteler başlamadan 1 gün önce bitecek şekilde inşaat aktivitelerine bağlanmıştır. İşin özeline göre belirlenen ve uyulması gereken talimatlar ise işin öncesinde de bazı gereklilikler olabileceği düşünülerek inşaat aktivitelerinden 1 gün önce başlayıp aktivite süresi boyunca devam ederek inşaat aktivitesinin bitimi ile bitecek şekilde bağlanmıştır. Bu sayede inşaat işleri aktivitesinde meydana gelebilecek herhangi bir gecikme veya erken bitimde talimat aktivite ile birlikte uzayıp kısalabilecektir. İş yerinde uyulacak işçi sağlığı ve iş güvenliği kuralları tutanağı talimatlara benzer şekilde inşaat aktivitesinden 1 gün önce başlayıp aktivitenin bitmesiyle bitecek şekilde düşünülmüştür. Fakat Mobilizasyon aşamasında daha öncesi olmadığı için imalat ile başlayıp imalat ile bitecek şekilde tasarlanmıştır. En çok kullanılanlardan biri olan prosedürler ise her kaleme özel olarak atanmıştır. Bağlanış türü olarak talimatlara benzer şekilde işten 1 gün önce başlayıp iş ile birlikte devam ederek sonlanması ile de bitecek şekilde düşünülmüştür.

Tehlike ve Risk Değerlendirme dokümanları inşaat işlerinin en başında mutlaka yapılması gereken bir belgedir. Fakat iş sahası doğası gereği sürekli değişken bir yapıya sahiptir. Bu açıdan her an için farklı riskler ortaya çıkabilmektedir. $\mathrm{Bu}$ şekilde düşünüldüğünden ötürü Tehlike ve Risk Değerlendirme dokümanları projede herhangi bir aktiviteye bağlı kalmadan proje başlangıcı ile başlayıp projenin bitişine kadar bitecek şekilde atanmıştır. Bu sayede projenin her aşamasında yeni riskler oluştuğunda bu dokümanların doldurulabilmesi sağlanmıştır.

Kaza Olay Tespit dokümanları hiçbir yöneticinin veya çalışanın doldurmak istemediği belgelerdendir. Çünkü bu esnada belirli bir takipten ziyade çok daha ciddi sonuçlar doğurabilecek bir durum söz konusudur. Kaza projenin her anında meydana gelebilecek bir durum olduğundan dolayı bu da risk değerlendirme dokümanlarına benzer olarak proje başlangıcı ile başlayıp proje bitişiyle sonlanacak şekilde tasarlanmıştır.

İşçi sağlığı ve iş güvenliği ile ilgili eğitimler normal şartlarda belirli periyotlarda iş yerlerinde gerçekleştirilir. Fakat çalışılan projede alt sigorta veya geçici görevlendirmeyle sürekli yeni çalışanlar işe dahil olmaktadır. Yeni başlayan çalışanlara da daha önceden eğitimli ve bilinçli olsalar dahi, yeni bir şantiyede ki risklerle ve tehlikelerle ilgili bilinçlendirmek adına 
eğitimler yapılması söz konusudur. Bu açıdan eğitimler proje başlangıcı ile bitişi arasında ki her süreçte önem sahibidir. Böylece belirli bir işten bağımsız her aktivitenin öncesinde bu eğitimlerin alınmış olması gereklidir.

Kontroller grubunda mesleki yeterlilik belgesi kontrolleri her aktivite yapılmadan 1 gün önce tamamlanması gerektiği şekilde ilgili aktiviteye tanımlanmıştır. İlgili aktiviteyi yapacak kişilerin o işin ehli olduğunun kontrolü bu sayede yapılabilecektir. Fakat yemekhane mutfak ve depolama gibi proje SEÇ kontrol listelerinin hazırlanması ve en önemli dokümanlardan biri olan İşçi Sağlığı ve İş Güvenliği İzleme ve Ölçme Planı Kontrolleri gibi kontrol evrakları tüm proje boyunca düşünülmelidir.

Acil durum evrakları adından da anlaşılacağı üzere beklenmedik her anda meydana gelebilecek bir durumdur. $\mathrm{Bu}$ açıdan acil durum planları projenin en başında hazırlanmalı ve ardından projenin sonuna kadar güncellenerek devam ettirilmelidir. $\mathrm{Bu}$ sayede inşaat tamamlanana kadar acil durum esnasında neler yapılacağı veya ekiplerin ve sorumluların kimler olacağı belirlenmiş olacaktır.

Son olarak şahsi koruyucu malzemelerin kullanımı, genel iş güvenliği talimatlarına uyulması, iş yeri alanın giriş prosedürleri, ziyaretçiler için güvenlik talimatları gibi genel olarak herkesin uyması gerektiği ve her an olabilecek durumlar proje başlangıç ve bitişine göre ayarlanmıştır. Böylece projede ki gecikme veya erken bitişlerde bu durumlar otomatikman ayarlanmış olacaktır. Burada en önemli noktalardan bir tanesi ise proje başlangıcı ile bitişi arasında devam edecek iş güvenliği aktivitelerinin aktivite türünün level of effort olarak belirlenmesidir. Level of effort aktivite türü belirlenen bir imalat aralıklarda faaliyet gösteren fakat tam olarak aktivite gibi düşünülmeyen bir aktivite türüdür. Bunun yapılmasının amacı eğer aktivite türü Task Dependent olarak belirlenirse proje başlangıcından sonuna kadar tanımlandığı için kritik yolu üstlenmesidir. Kritik yolu diğer inşaat aktivitelerine aktarması açısından bu şekilde çözümlenmiştir. Genel proje boyunca ki kalemler Şekil 7'de gösterilmiştir.

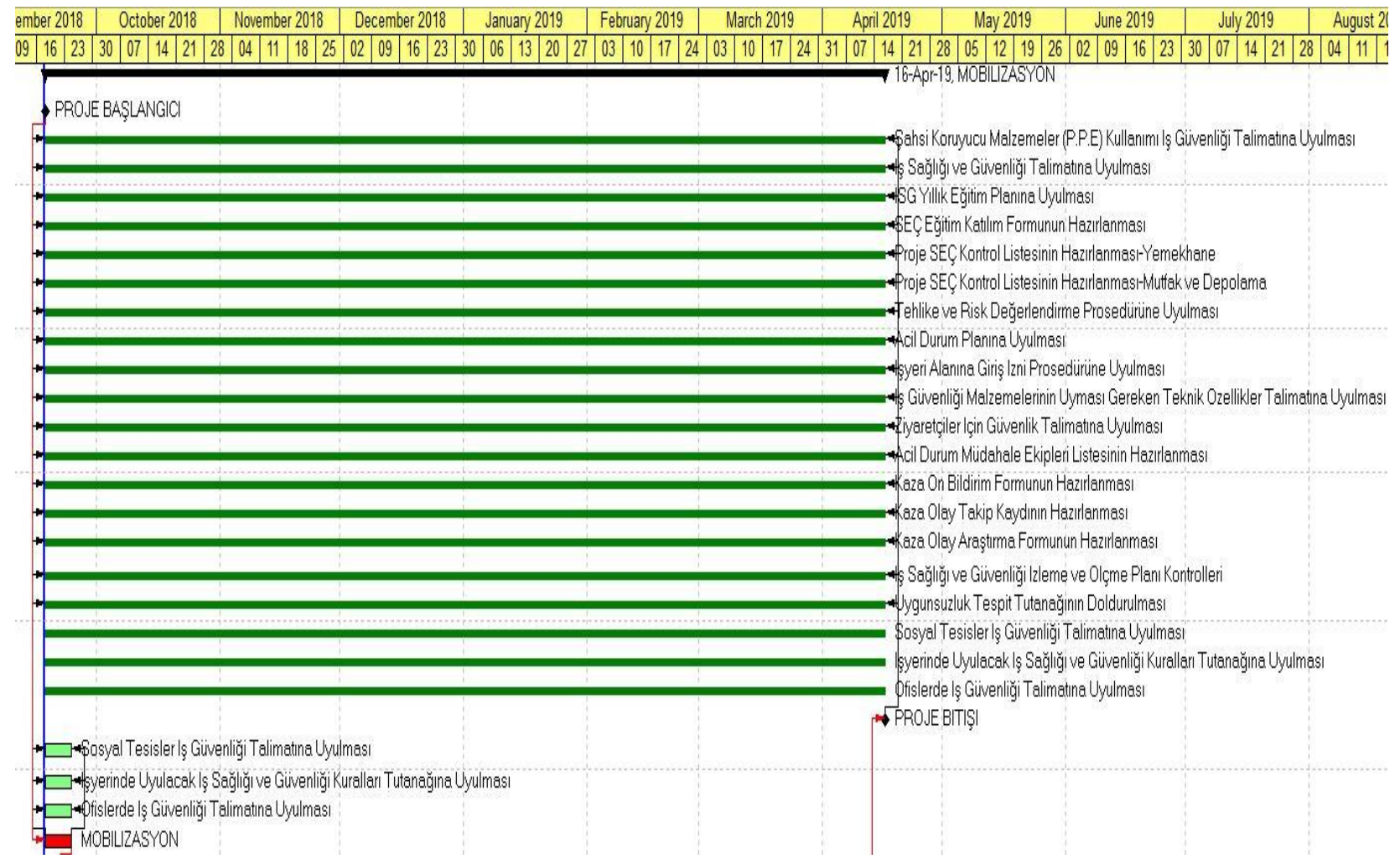

Şekil 7. Mobilizasyon aktivite akış şeması. 


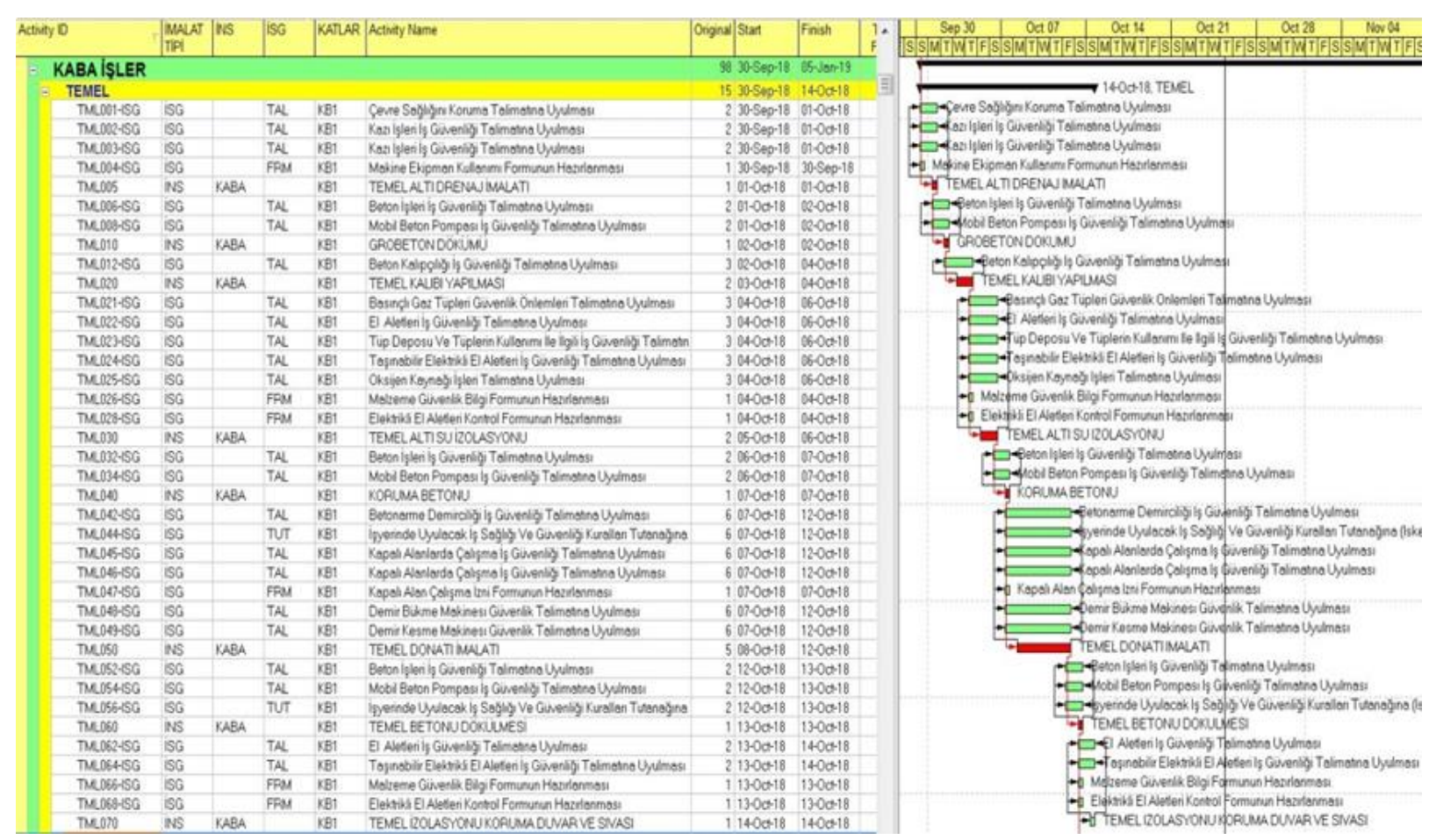

Şekil 8. Kaba işler temel bölümü aktivite düzeni ve akış şeması.

Belirtilen sistemler doğrultusunda inşaat işleri iş programı ile işçi sağlığı ve iş güvenliği yönetim sisteminin entegrasyonu yapılmıştır. Tüm iş kalemleri için ayrı ayrı bu entegre akış şemaları oluşturularak projenin başından sonuna kadar tüm aktivitelere dair güvenlik planlaması kolaylıkla sağlanabilir. Kaba işlere ait akış şeması Şekil 8'de görülebilir.

İşçi sağlığı ve iş güvenliği ile inşaat iş programını entegre ederken konut projesinin planlama aşamasında yapım yöntemi, tasarım, miktar ve süre değişimleri gözardı edilerek ele alınmıştır. İş planı yapılırken işin başında sabit bir metod işin başında belirlenmiş ve buna göre proje sonuna kadar devam etmiş. Aynı zamanda herhangi bir tasarım değişikliği veya miktar değişikliği gibi durumlar söz konusu olmadığı düşünülmüştür. Fakat inşaat sektörü yapısı gereği bir çok belirsizliği içerisinde barındırmaktadır. $\mathrm{Bu}$ belirsizlikler doğrultusunda başta yapılan planlamadan sapmalar tabii ki gerçekleşebilmektedir. Önemli olan bu değişiklikleri minimuma indirmeye çalışmak ve sonucunda nihai programı işin başında planlayabilmektir. İşin başında planlama yapıldıktan sonra inşaat süresince değişebilecek bazı faktörler aşağıda verilmiştir:

- Yapım Metodu Değişikliği,

- Tasarım Değişiklikleri,

- Miktar Değişikliği,

- Süre Değişikliği.

Yapım metodu değişiklikleri inşaat projelerinde sık görülen faaliyetlerdendir. İşin başında planlanan metodun bir çok faaliyetten etkilenerek devre dişı kalması durumlarında proje yöneticileri farklı bir çözüme gidebilirler. $\mathrm{Bu}$ da entegre bir güvenlik sisteminde yeni tehlikeler doğabileceği anlamı taşımaktadır. $\mathrm{Bu}$ sebeple eğer inşaatın herhangi bir bölümünde yapım değişikliği yapılacaksa yeni risk analizleri yapılması gerekmektedir. Risk analizlerinin ardından bütünleşik sisteme yeni form, prosedür ve talimat gibi yeni doküman eklentileri yapılacaktır. Burada önemli olan konu metod belirlendikten sonra işin acil olması göz ardı edilerek önce güvenlik tedbirlerinin alınmasıdır. Aynı zamanda eski metoda ait güvenlik dokümanlarının planlama tablosundan çıkartılmasının karmaşadan kurtulmak açısından yararı bulunmaktadir.

Yapım metodu değişikliklerinde yeni dokümanlar geldiğinde işin özelinde inşaat işi ile işçi sağlığ 1 ve iş güvenliği dokümanları arasında $\mathrm{ki}$ ilişki tipinde değişiklikler gözlenebilir. Bazı formlar iş özelinde belki de 1 gün öncesi yerine herhangi bir yerden izin alınması gerektirdiğinden dolayı 1'den fazla gün öncesinden doldurulması istenebilir. Bu açıdan inşaat işlerinde bir gecikme olmaması açısından dokümanların iyi analiz edilip ilişki tiplerinde ona göre girilmelerinde yarar olabilir.

Tasarım değişiklikleri ise projelerimizin vazgeçilmezleri arasında yer almaktadır. Mal sahibi ön tasarım ve tasarım aşamasında isteklerini açıkça ifade eder. Fakat sonrasında yapım esnasında zorunlu veya keyfi sebeplerden dolayı tasarım değişikliklerine oldukça rastlanılmaktadır. $\mathrm{Bu}$ açıdan tasarım değişikliği gerçekleştiği anda işçi sağlığı ve iş güvenliği gözü ile de durumu incelemek gerekir. Örneğin; bir işi bir işçi normal ayaklarının üzerinde durduğu seviyeden gerçekleştirdiğinde herhangi bir 
yüksekte çalışma riski söz konusu değildir. Fakat tasarım değişikliğinden ötürü iş̧̧i işi yapmaya yetişemeyeceği düşünülürse, bu işçi ve iş için yüksekte çalışma riskleri devreye girecektir. Bu yüzden o iş kapsamında yüksekte çalışma güvenlik dokümanları orada bulunmalıdır. Bu tarz değişikliklerde pek fazla ilişki tipinde oynama gerçekleşmemektedir. Fakat tasarım tamamen farklı bir metoda yol açacaksa ilişsi tiplerinde de farklılıklar meydana gelebilmektedir. Aynı şekilde tasarımın durumuna göre, malzeme değişiklikleri gibi konularda başta prosedür ve talimatlar olmak üzere iş̧̧i sağlığ 1 ve iş güvenliği dokümanları da değişebilmektedir.

Metrajlar genelde projenin başında net olarak çıkartılsa da sahada uygulanma esnasinda tasarım ve yapım metodu değişiklikleri göz önüne alındığında değişiklik gösterebilmektedir. Miktarın değişmesi süreyi değiştirebilir. Aksi halde sürenin sabit kalmasını istiyorsak ya çalışan yoğunluğunu artırmamız ya da bir işçiden mesai yapması veya daha verimli çalışmasını beklememiz gerekir. Bu da iş̧̧inin dikkat seviyesini dağıtacağından veya acele çalışacağından dolayı kaza risklerini de artırmaktadır. $\mathrm{Bu}$ açıdan yönetim sistemleri açısından, dokümanların ilişki tipleri açısından ve yeni dokümanlar açısından değişiklik olmayacaktır. Fakat işin daha dikkatli, daha güvenli gerçekleşmesi için daha çok önem verilmesi gerekecektir. Konut projesinnde yapılan bu sistemde metrajdan ve süreden kaynaklı değişiklikler olduğunda sistem değişen süre ile birlikte hareket edecek seviyede planlanmıştır. Fakat yine de geniş kapsamlı bir bütünleşik planlama ile daha spesifik işe bağlı küçük detaylı planlamalar yapılırsa güvenlik riskleri oldukça düşecektir.

Akış şeması her iş kalemi için ayrı ayrı yapılıp şantiye başında oluşturulduğu taktirde kişiden bağımsız olarak her türlü çalışan için yönlendirici bir görev üstlenecektir. İşin başlangıcında konuya hakim bir çalışanın işten çıkma durumunda ise bu kurallar sabit kalacağı için yeniden adapte olması kolaylaşacaktır. Takip edilen iş akış şemaları yardımıyla şantiye ve ofis bölgelerinde bütünleşik bir işçi sağlığı ve iş güvenliği yönetim sistemi oluşturulmuş olacaktır.

Oluşturulan bu yönetim sisteminin en önemli katkılarından biride tartışmasız insanların bilinçlenmesini sağlayarak kazaların, meslek hastalıklarının, hatta ölümlerin önüne geçilmesidir. İnsanlar görsel bir tablo üzerinde gördükleri bir şemayı bir kez de olsa uyguladıklarında hafizalarında kalıcı olarak yer alacağından dolayı bütünleşik bir iş̧̧ sağlığı ve iş güvenliği yönetim sisteminin olmadığ 1 durumlarda bile talimatlara ve prosedürleri uymaya ve formları doldurmaya özen gösteriyor olacaklardır.

Kaynak kısmında ise, bu makale kapsamında sadece işçi sağlığı ve iş güvenliği dokümanları atanmıştır. Fakat daha ileri bir bütünleşik sistemde ilgili işin sorumluluğunun kim olacă̆ını belirlemek için sorumluluk kaynağı ve o iş için yapılması için ne gibi ekipmanlara ihtiyaç olduğunu anlamak için malzeme ve ekipman kaynağı atanabilir. Bununla ilgili bir örnek projenin gaz işleri bölümüne uygulanmıştır ve Şekil 9'da gösterilmiştir. Bahsedilen örneğe göre personel sorumluluğu olarak İSG uzmanı, Şantiye şefi, Saha mühendisi veya vinç veya ekipman operatör sorumluluk listesine girebilir. Aynı şekilde doküman hazırlanırken kullanılack her türlü ekipmanda buraya işlenebilir. Oksijen kaynağı işi sırasında herhangi bir patlayıcı gazın bulunması oksijen kaynağından çıkabilecek bir kıvılcım patlamaya sebebiyet verebileceğinden dolayı bu şekilde bir örnek oluşturulmuştur.

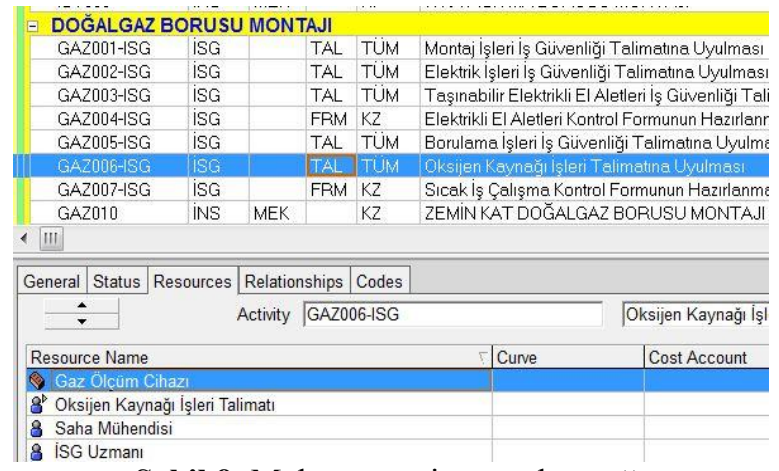

Şekil 9. Malzeme ve iş gücü kaynağı.

Yapılan akış şemaları ve bütünleşik sistemler teknolojinin bu konuda da gelişimini tetikletip daha kullanışlı programlar ve sistemler oluşmasına sebebiyet verebilecektir. Bütünleşik iş akış şemaları her iş kalemi için oluşturulmalıdır. Örneğin kazı işleri için düşünülürse, öncelikle proje başlangıcı ve proje bitişleri akış şemasının sırasıyla başında ve sonunda bulunmaktadır. Proje başlangıcından proje sonuna kadar spesifik olarak sadece bir işe bağımlı olmayan, istisnasız her türlü işte uyulması gereken talimatlar, prosedürler, hazırlanması gereken formlar ve acil durum planları gibi işçi sağlığı ve iş güvenliği yönetim sistemi dokümanları proje başlangıcından proje bitişine direkt olarak bağlanmaktadır. $\mathrm{Bu}$ dokümanlar hazırlanmadan önce iş asla başlamamalı, iş öncesinde ki evraklar tamamlanmış fakat iş sırasında belirli prosedür ve talimatlara uyulmadığ taktirde de derhal iş durdurulup gerekli önlemler alındıktan sonra tekrar aktivasyona geçilmesi gerekmektedir. Bahsedilen faktör iş akış şemasında 'talimatlara, prosedürlere tutanaklara uyuldu mu? Formlar hazırlandı mı"' ibaresi ile yönlendirilmesi yapılmıştır. Son olarak ise, işin kendine özgü akışı şemanın içine dahil edilerek akış şeması bitirilebilir.

\section{SONUC ve DEĞERLENDİRMELER}

İşçi sağlığı ve iş güvenliği ile ilgili yapılan çalışmalar her ne kadar yüz ylllar öncesine dayansa da, gerçek anlamda önem verilmeye başlanması ve bu doğrultu da her geçen gün verilen önemin artması yaklaşık son 30 yıla dayanmaktadır. Verilen önem kapsamında sahada 
birçok güvenlik tedbiri metodu bulunmuş ve uygulanıyor olsa da iş kazaları ve meslek hastalıkları halen devam etmektedir. Bahsedilen iş kazaları ve meslek hastalığı sonucu ölümleri ve yaralanmaları bir de inşaat döngüsünün geri planında, daha net ifade etmek gerekirse tasarım ve planlama aşamasında değerlendirmek gerektiği düşünülmüştür. Yapılan literatür taramasında da görüldüğü üzere 1990'l yıllardan itibaren işçi sağlığı ve iş güvenliği ile proje yönetim döngüsünün beraber ele alınması gerektiği sonucuna varılmıştır. İş güvenliği konularının proje yönetime entegrasyonu anlamında ise çeşitli metotların geliştirilmiş olduğu görülmektedir.

İş kazalarının ve meslek hastalıklarının yaşanmasının en büyük sebeplerinden biride proje yönetim döngüsünün en önemli yapı taşlarından bir tanesi olan süre kavramı ile işçi sağlığ 1 ve iş güvenliği kavramını birleştiren herhangi bir sistemin bulunmamasıdır. Yapılan çalışmalar incelendiğinde herhangi bir projede kullanılan süre entegreli bir işçi sağlığı ve güvenliği sistemi görülmemektedir. Günümüze kadar işçi sağl1ğ ve iş güvenliği ile ilgili birçok tedbir düşünülse de süre odaklı ve entegreli bir sağlık planı düşünülmesinin temel nedenlerinden bazıları ve bununla ilişkili bu iki sistemin entegrasyonu sirasinda insanların problem olarak görebileceği bazı hususlar aşağıda bahsedilmiştir:

- Zaman ve bütçe: Bu makale kapsamında yapılan çalışmada olduğu gibi, yapılan çoğu çalışmada, CPM metodunun üzerine ayrıca oluşturulup entegre edilmesi gereken bir İSG yönetim programı oluşturulması gerekmektedir. Her proje tek ve tekrarlanamaz olduğu için, yapılan aktiviteler de farklı olacaktır. Bu yüzden her proje için ayrı bir ISG yönetim programının oluşturulması gerekmektedir. $\mathrm{Bu}$ da firmalar tarafindan zaman ve iş yükü gibi görülebilir.

- Sistemin karmaşıklığı: Bir inşaat projesi, birbirine karmaşık bir şekilde bağlanmış, çok sayıda aktivite içermektedir. Günümüzde, firmalar şantiyelerde sadece süresel planlamanın oluşturulması ve takibini bile bir hayli zor olarak görüyorken, bu sisteme ISG yönetim sisteminin entegre edilmesiyle kullanılabilirlik açısından firmalara zorluk hissi katabileceği düşünülebilir.

- Yönetimsel yaklaşım: Günümüzde inşaat projelerinde işçi sağlığ 1 ve iş güvenliği ne yazık ki gereken önemi görmemektedir. $\mathrm{Bu}$ noktada, makalede önerilen bu sistemin, inşaat firmaları tarafından kabul görüp görmeyeceği bir soru işaretidir. Şirketler tarafından, işçi sağlığı ve iş güvenliği önlemlerinin alınmasında ortaya çıkan maliyetler bir külfet olarak görülürken, iş kazaları sonucu ortaya çıkan yüksek maliyetler ne yazık ki göz ardı edilmektedir.

- Personel yeterliliği problemi: İş kazalarının ağırlıklı olarak orta ve küçük çaplı inşaat şirketlerinde daha fazla meydana geldiğinden bahsedilmişti. Orta ve küçük çaplı inşaat şirketlerinin birçoğunda maalesef ki personellerden mevcut çalışma saatlerinde kişinin yapabileceğinden fazla sorumluluklar yüklenmektedir. $\mathrm{Bu}$ nedenle bir de üstüne personelin bu sorumluluğu alması, sistemin etkili ve ne derece ciddiyetle kullanılabilirliğini düşündürmektedir.

Bilindiği üzere, inşaat proje yönetimi altı temel başlık (genel proje yönetimi, süre, maliyet, kalite, işçi sağlığ1 ve iş güvenliği yönetimi ve sözleşme idaresi) ve bunlara yeni eklenen sürdürülebilirlik, bina enformasyon modellemesi ve risk yönetimi başlıklarından oluşmaktadır. Yapılan yanlışlardan birisi, tüm bu başlıkları ayrı uzmanlık alanları olarak görmek olup, tüm bu temel başlikların birbirleriyle tümleşik bir yapıda bir sistem oluşturduğu gözden kaçırılmaktadır. Sistem yaklaşımı açısından bakıldığında, tüm bu başlıklar inşaat proje yönetim sisteminin birbiriyle ilişkili öğeleridir ve ancak her biri öyle anlam kazanmaktadır. İnşaat proje yönetim sisteminin bir alt sistemi veya başka bir ifadeyle yürütülmesi için gerekli bir sistem olan bilgi/belge yönetim sistemi de bu öğelerin içiçeliğini gerektirmektedir. Genel proje yönetimi (prosedürler, iletişim kanalları, sorumlulukların belirlenmesi), etkin bir bilgi/belge takibi yapılamaz. Süre yönetimi entegre bir başlık olarak görülmediğinde, inşaat projesi boyunca herhangi bir anda hangi iş kalem(ler)inin ne zaman başlayacağ̀, ne zamana biteceği, öncül ve ardıl işlemlerin neler olacağ 1 , bu iş kalem(ler)inin ne kadara maliyetle gerçekleştirileceği, nasıl bir kalitede yapılacağı, sözleşmede hangi maddeler çerçevesinde belirlendiği, ne gibi riskler taşıdığı, hangi bilgilerin bina enformasyon modeline aktarılacağ da bu makalede altı çizildiği üzere işçi sağlığı ve iş güvenliği açısından hangi sağlık ve güvenlik riskleri taşıdığı önceden bilinemeyecektir. Sağlık ve güvenlik konularını tamamen iş müfettişlerince gerçekleştirilen denetimlere veya iş güvenliği uzmanlarınca yapılan rutin izlemelere indirgemek, İSG yönetimini entegre proje yönetim sisteminden çekip çıkarmak anlamına gelecektir. Bu çalışmada, İSG yönetiminin olmazsa olmaz bir proje yönetim başlığı olduğu vurgulanmış ve bu başlı̆̆ın nasıl entegre edileceğine dair pek çok öneriler getirilmiştir.

Bahsedilen eksiklikler göze alınarak makale kapsamında da konut projeleri için kolay uygulanabilir bir süre entegreli işçi sağlığı ve iş güvenliği yönetim sistemi kurulmaya çalışılmıştır. Bu yönetim sistemi hedef kitle olarak inşaat, elektrik ve makine mühendisleri, mimarlar ve iş güvenliği uzmanlarına yöneliktir. Burada şu hususların altı çizilmelidir; inşaat projeleri proje öncesinde ve süresince, mimarların, elektrik ve makine mühendislerinin sürekli birlikte çalışmasını gerektiren süre, maliyet ve sözleşme 
şartları kısıtlarının olduğu projelerdir. İşçi sağlığı ve iş güvenliği açısından bakıldığında da bu, elektrik işlerinde, mekanik/tesisat işlerinde, mimari tasarım detaylarında, inşaat mühendisinin ve onunla birlikte hareket etmesi gereken iş güvenliği uzmanının sürekli bir risk değerlendirmesini, yeri geldiğinde tehlikeleri önleme ve riskleri azaltma hiyerarşisi kapsamında düzeltici ve önleyici faaliyetleri işaret etmektedir. Sözgelimi bir doğalgaz 1sitma sistemi kurulumundaki riskler makine mühendisinin, dış cephedeki bir detayın inşasındaki zorluklar bir mimarın (yeri geldiğinde tasarım revizyonunu da içeren), binanın elektrik sistemindeki riskler ve olası sonuçları bir elektrik mühendisinin katılımı olmadan çözüme kavuşturulamaz. Tüm bu hususlar da, her iş kaleminin takibini, her iş kalemiyle ilişkili tarafları, iş programı kapsamında takip etmeyi ve bilgi/belge izleme/takip sürecini gerektirir. Bu bakımdan sunulmakta olan çalışmanın bir yaklaşım sunduğu ve aynı zamanda gelecekte yapılacak çalışmalara (maliyet, kalite, sözleşme konularını da kapsayan) yardımcı olacağı düşünülmektedir. İşçi sağlığı ve iş güvenliği yönetim sistemi ile inşaat işleri planlamasının entegrasyonundan doğan entegre program sayesinde inşaat alanında bulunan tüm tarafların işçi sağlığı ve iş güvenliği bilinçleri artacak ve iş güvenliği uzmanları ve teknik ekip her aktivitenin öncesinde, sonrasında ve sırasında nelerin yapılması gerektiğgini bilecek ve bu konuda hazırlıkların yapılmasının daha rahat olması sağlanacaktır.

Makalenin uygulama bölümünde yapılan çalışma sayesinde sistemin kullanılabilirliği denetlenmiş ve kolaylıkla entegre edilebileceği ve uygulanabileceği sonucuna varılmıştır. Normal süresel iş programını oluşturmaktan daha fazla zaman gerektireceği tartışılmaz bir gerçek olsa da, bu sistemin oluşturulmasından kaynaklı en başta kurtarılacak her can bu zaman kaybının ne derece önemsiz olacağının bir kanıtıdır. Aynı zamanda can kaybından sonra mal kayıpları, ödenecek tazminatlar ve meslek hastalığı nedeniyle çıkan problemlerinde önüne geçilebileceği düşünülürse bu bir zaman kaybı olarak düşünülmemelidir. Öte yandan iş programının hazırlanma sürecinin yalnızca süresel planlama yazılımlarını kullanan teknik elemanların, iş kalemlerini belli bir sıra ve mantık içinde sıralaması olmadığı bu çalışmayla anlaşılmaktadır. İş programının hazırlanma sürecinin, gerek iş̧̧i sağlığı ve iş güvenliği açısından, gerekse de inşaat proje yönetimi ilkeleri açısından bakıldığında farklı uzmanlıkların katılımını gerektirdiği, yapım aşamasından önce bu tarafların katılımının pek çok hususu kolaylaştıracağı belirtilmelidir. Sunulan çalışma, her iş kalemiyle ilişsili mümkün olan en fazla bilgiyi toplamayı gerektirmekte, bu da daha önce belirtildiği üzere, yalnızca inşaat mühendislerinin değil, mimar, iş güvenliği uzmanı, elektrik ve makine mühendislerinin (tesis gibi projelerde kimya mühendisleri ve ilgili diğer disiplinler de dahil edilmelidir) iş programı sürecinde bulunmasının avantajlarını da ortaya koymaktadır. Zira herhangi bir iş kalemindeki riskler, bu riskleri ortadan kaldırma/azaltma faaliyetleri farkl 1 disiplinlerin bilgisinden yararlanmayı zorunlu kılmaktadır.

Makalenin bir diğer avantaj1 olarak ise şantiye uygulamaları esnasında ki teknik personele katkısı da düşünülebilir. İşçi sağllğı ve iş güvenliği yönetim sistemi ile iş programının entegrasyonu iş güvenliği uzmanlarına şantiye sahasında yapılan işler açısından bilgi, birikim ve tecrübe kazandırırken, inşaat, elektrik, makine mühendislerine, mimarlara ve sahada sorumlu teknikerlere de iş güvenliği konusunda ki bilincini artırmaktadır.

Aynı zamanda Türkiye'de inşaat sektöründe bulunan firma sayısı oldukça fazladır. İşçi sağlığı ve iş güvenliği hassasiyetinin gelişmesiyle yeni bir iş olanağı ortaya çıkabilir. Her firma uygulamış olduğu projelerde 1 adet personeli bu iş için görevlendirdiği taktirde çalışma hayatında ki iş bulamayan bir çok kişiye umut olacaktır.

Bir diğer avantajı ise, bu zamana kadar işçi sağlığı ve iş güvenliği konuları planlama departmanından tamamen bağımsız düşünülmektedir. $\mathrm{Bu}$ çalışma sayesinde işçi sağllğı ve iş güvenliği konuları henüz planlama aşamasındayken ortaya konulmaya başlanacak ve yönetim ekibininde bilinçlenmesiyle daha organize yürüyecektir. $\mathrm{Bu}$ sayede planlama ekipleri inşaat işlerinin yanında işçi sağlığı ve iş güvenliği konularında da hakimiyet sahibi olacaklardır.

Çalışma literatüre kattığı değer anlamında değerlendirildiğinde ise, işçi sağlığ 1 ve iş güvenliği ile proje yönetiminin entegrasyonu anlamında çalışmalar yapıldığı görülse de, bu entegrasyon kapsamında ISO 45001 standardiyla ve sektörde uzman iş güvenliklerinin fikirleri alınarak oluşturulmuş entegre bir iş güvenliği yönetim sistemine rastlanmamıştır. İşçi sağlığı ve iş güvenliği yönetim sistemi ve inşaat işleri iş programının entegrasyonuna benzer çalışmaların devamı olması niteliğinde ve bu doğrultuda iş kazaları ve meslek hastalıklarını önleme amacıyla düşünülen bazı öneriler aşağıda verilmiştir:

- Uygulanabilir sistemlerin kurulmasi: 1997 yılında ABD'de Kartam tarafindan yapilan araştırmada da bahsedildiği gibi iş programları kendi içinde çok katmanlı ve karmaşık olup takibi oldukça zordur. 1997 yılından günümüze gelindiğinde teknolojinin gelişmiş olmasiyla bu alanda kullanılan programlar daha kullanıcı dostu hale gelmiştir. Ancak bu makalede yapılan çalışma sonucunda da görülmüştür ki, entegrasyon bu sistemi daha karmaşıklaştırmaktadır. Bunun sebebi, İSG yönetim sisteminin iș programına aynı ortamda dahil edilmesidir. Bunun önüne geçebilmek için farklı bir yazılım geliştirilebilir. Bu yazılımın Primavera P6 gibi iş programı oluşturulan yazılımlarla 
entegrasyonu sağlanabilir.

- Sistem kurulum maliyeti ile iş kazası maliyetlerinin karşılaştırılması: Sistem kurulumu sirasinda harcanacak olan ekstra zaman ve iş gücünün şirketler tarafından kabul edilebilmesi için, proje yapım aşamasında meydana gelebilecek iş kazaları sonucunda oluşacak maliyetlerin, sistemin oluşturulması için oluşacak maliyet ile karşılaştırılarak, bu sistemin fayda sağlayıp sağlamadığ ölçülmelidir.

- Yasal düzenleme: Süresel planlama ve İSG programının entegrasyonu sonucunda oluşan sistemin kullanılabilirliğini artırmak amaciyla, özel sektöre müdahale edilemiyor olsa da, ilk aşamada kamu ihalelerinde bir düzenlemeye gidilebilir. Bu kapsamda, Kamu İhale Kanunu düzenlenerek, şirketlerden istenen iş programının yerine, süresel planlama ile ISG programının entegrasyonunun sağlandığı bir program istenmelidir [9].

- Pratiğe uygun çalışmalar: İşçi sağlığı ve iş güvenliği ile iş programının entegrasyonu kapsamında yapılacak çalışmalarının teorik çalışmalardan ziyade pratikte uygulanabilecek çalışmalar olabilmesine önem gösterilmelidir.

- Farklı tip projelere uygulanmasi: Bu makale kapsaminda konut projelerine uygun bir entegre yönetim sistemi kurulmuştur. Devamı olabilecek çalışmalarda ise farklı proje türlerine göre sistemler kurulabilir.

Sonuç olarak, bu makalede ki iş güvenliği entegre yönetim sistemi kavramının uygulama sahasında kabul görülebilirliği açısından mevcut çalışmaların geliştirilmesi ve ilave olarak yeni çalışmaların yapılması gerekmektedir. Literatür çalışmalarında da belirtildiği üzere işçi sağlığı ve iş güvenliği konusunda entegre yönetim sistemleri geçmişte üzerinde durulmayan konular iken, günümüzde önem verilmeye başlanmıştır. Bu kapsamda işçi sağlığı ve iş güvenliği yönetim sistemi ile proje yönetim döngüsünün entegrasyonunun uygulanamayacak bir çalışma olarak görülmemeli ve geliştirilmesine yönelik çalışmalar yapilmalidir.

\section{KAYNAKLAR}

[1] Uluslararası Çalışma Örgütü (ILO), 2016, Türkiye İş Sağlığı ve Güvenliği Profili

[2] Karadeniz, O., 2012, Dünya'da ve Türkiye'de İş Kazaları ve Meslek Hastalıkları ve Sosyal Koruma Yetersizliği, Çalışma ve Toplum, 2012/3.

[3] TMMOB, 2018, Makine Mühendisleri Odası ISG Raporu.

[4] Korea Occupational Safety and Health Agency 2010 www.kosha.or.kr,. 8.30.

[5] Loosemore, M., Andonakis, N., 2007. Barriers to implementing OHS reforms - the experience of small subcontractors in the Australian construction industry.
International Journal of Project Management 25, 579588.

[6] İNTES, 2018. Türkiye İnşaat Sanayicileri İşveren Sendikası, İnşaat Sektörü Raporu.

[7] Stanton, W., and Willenbrock, J. (1990). Conceptual framework for computer-based construction. safety control. J. Constr. Engrg. And Mgmt., ASCE, 116(3),s.383-398.

[8] APM, (2000), Body of Knowledge, Association for Project Management, Orton Southgate.

[9] Sevim, M, Gürcanlı, G. (2019). İşçi Sağliği Ve İş Güvenliği (İsig) Sisteminin İnşaat Uygulama İş Programina Entegrasyonu, Beykent Üniversitesi Fen ve Mühendislik Bilimleri Dergisi, 11 (2), 19-33. DOI: 10.20854/bujse.447676

[10] ANSI/AIHA Z10-2005-2012: American National Standards Institute/American Industrial Hygiene Assosication Occupational Health \& Safety Management Systems

[11] Egan, J. (1998). Rethinking Construction, scope for improving the quality of UK ConstructionLondon, Construction Task Force.

[12] Crosby, P. B. (1979). Quality is Free: The Art of Making Quality Certain. New York, McGraw-Hill Book Co.

[13] Hinze, J. and H. W. Parker (1978). "Safety: Productivity and Job Pressures." Journal of the Construction Division 104(1).

[14] Tarrants, W.E., (1980). The Measurement of Safety Performance, Garland STPM Press, New York. [15] Levitt, R., and Kartam, N. (1990). Expert systems in construction engineering and management: state of the art, Knowledge Engrg. Rev. J., 5(2), s.97-125.

[16] Kartam, N. (1997) Integrating safety and health performance into construction CPM. ASCE Journal of Construction Engineering and Management, 123(2), 121-6.

[17] Saurin, T.A., \& Formoso, C.T., \& Guimarares , L.B.M.,(2001), Integrating Safety into Production Planning and Control Process : An Explotary Study, In Proceedings of the 9th annual conference of the international group for lean construction, Singapore.

[18] Gürcanl1, E. 'Health \& Safety Management Lecture Note', Safety Management in Construction Projects, Istanbul Technical University, Istanbul, (2018).

[19] Davies, I., K., (1971). The Management of Learning, London: McGraw-Hill

[20] Osborn, A.F. (1957). Applied imagination: Principles and procedures df creative problem solving (third rev, ed,). New York, NY: Charles Scribner's Sons.

[21] Orlich, I. (1990). The Mioritic Space as Poutical Subversion: The Poetry of Marin Sorescu. Southeastern Europe, 17(1), 119. https://doi.org/10.1163/187633390X00019.

[22] Demirel, Ö. (1995). Genel Öğretim Yöntemleri, Usem Yayınları II, Ankara. 